\title{
Associazione Canonistica Italiana (a cura di), Diritto canonico $e$ „Amoris laetitia”, Città del Vaticano, LEV, 2019, ss. 234.
}

W dniach 3-6 września 2018 roku, w Catanzaro Lido, odbył się już 50. Kongres Krajowy Stowarzyszenia Kanonistyki Włoskiej (Associazione Canonistica Italiana). Tematem obrad była Adhortacja apostolska papieża Franciszka Amoris laetitia z 19 marca 2016 roku. Owocem kongresu stała się wskazana wyżej publikacja (zawierająca na początku: s. 7-9) wspomnienie o zmarłym kanoniście włoskim Carlo Gullo).

Po krótkim wprowadzeniu Erazma Napolitano, przewodniczącego Stowarzyszenia (s. 11-12), czytelnik zapoznaje się z dziesięcioma przedłożeniami zaprezentowanymi podczas kongresu; dotyczą one różnych aspektów Amoris laetitia oraz kwestii związanych z tematyką tego dokumentu.

Kard. Vincenzo Paglia, wielki kanclerz Papieskiego Instytutu Jana Pawła II, podjął temat: „Implikacje eklezjologiczne Amoris laetitia” (s. 13-24). Autor zwraca uwagę na to, by - mając na względzie wymieniony dokument papieski - nie traktować rodziny jedynie jako „odbiorcy” działań formacyjnych, duszpasterskich lub sakramentalnych, lecz uznawać ją jako podmiot tych akcji. Sugeruje, by przyjąć nowy styl kościelny, dla którego sam Kościół powinien być rodziną, czyniąc rodzinnym całe duszpasterstwo. W takiej perspektywie należałoby umocnić więź między sakramentem małżeństwa i rodziną. Zdaniem autora, w KPK brakuje prawa rodzinnego, podczas gdy uwagę koncentruje się przede wszystkim na sakramencie (małżeństwa) jako takim. Mówiąc o zakazach w stosunku do tych, którzy nie mają uregulowanej sytuacji małżeńskiej, wyraża zakłopotanie, że nie są określone w jednym kanonie KPK. 
Héctor Franceschi w referacie: „Wymiar prawny w duszpasterstwie rodzinnym w świetle Amoris laetitia" (s. 25-47) postuluje przezwyciężenie wizji redukcjonistycznej prawa, w szczególności małżeńskiego, według której prawo miałoby się zajmować przede wszystkim nieważnością małżeństwa, mając niewiele do zaoferowania duszpasterstwu małżeńskiemu i przeciwstawiając prawo duszpasterstwu. Autor podkreśla, że małżeństwo i rodzina są rzeczywistościami pierwotnymi i oryginalnymi, w których jednak wymiar prawny nie jest czymś „nabytym”, lecz naturalnym. Dlatego też prawo dotyczące małżeństwa i rodziny powinno być stanowione w szerszym obszarze prawa naturalnego i przy jasnej świadomości, że nie istnieją małżeństwo i rodzina kanoniczne lub cywilne, lecz istnieją regulacje kanoniczne i cywilne instytucji, które są jedyne w swojej naturze. Dlatego też, stwierdza Franceschi, należy zauważyć, iż dokument duszpasterski (jak Amoris laetitia) nie może nie być jednocześnie dokumentem również prawniczym.

Benedict Ndubueze Ejeh prezentuje tekst zatytułowany: „Przygotowanie małżeńskie między magisterium, prawem i duszpasterstwem” (s. 49-69), w którym w ujęciu historyczno-analitycznym ukazuje ewolucję instytucji przygotowania do małżeństwa. Zauważa, że Adhortacja Amoris laetitia promuje katechumenat przedmałżeński. Nawiązując zaś do dokumentu Papieskiej Rady ds. Rodziny o przygotowaniu do małżeństwa oraz do Dyrektorium duszpasterstwa rodzin w Kościele we Włoszech, przedkłada własną refleksję de lege ferenda akcentując konieczność uwzględnienia wzajemnego przenikania charakteru jurydycznego i duszpasterskiego.

„Formacja sprawujących posługę wobec rodziny” to tytuł wystąpienia bp. Vincenzo Bertolonego (s. 71-87), w którym kładzie nacisk na potrzebę formowania posługujących w duszpasterstwie rodzin. Omawia też Instrukcję Kongregacji Wychowania Katolickiego pt. „Studia prawa kanonicznego w świetle reformy procesu małżeńskiego”.

Miguel A.A. Ortiz publikuje obszerny tekst pt. „Charakter kościelny i wpływy cywilne procesu na nieważność małżeństwa” (s. 89130). Omawia w nim koncepcję Franciszka dotyczącą reformy procesu nullitatis matrimonii. Porusza więc następujące kwestie, które wzięto 
pod uwagę w przeprowadzeniu reformy: naturalna skłonność do małżeństwa, centralna rola zgody małżeńskiej, charakter publiczny małżeństwa, charakter deklaratywny procesu, uprzywilejowanie małżeństwa (favor matrimonii) i gwarancje ochrony. Autor wypowiada się następnie w kwestii waloru dowodowego oświadczeń stron, odnośnych regulacji KPK z 1983 roku, Motu proprio Mitis Iudex Dominus Iesus. Zwraca też uwagę na prudentia iuris (jako sztukę, która pozwala stosować normy prawne według ratio legis), porusza sprawę skutków cywilnych orzeczeń kościelnych w sprawach małżeńskich (we Włoszech), a także inne kwestie $\mathrm{z}$ zakresu prawa procesowego. Wydaje się, że przedłożenie to zawiera zbyt wiele wątków tematycznych.

Spod pióra Francesco Catozzelli wyszedł tekst zatytułowany: „Integracja we wspólnocie chrześcijańskiej wiernych w sytuacji małżeństw nieregularnych" (s. 131-157). Swoją refleksję autor rozpoczyna od dyrektyw udzielonych przez Jana Pawła II uczestnikom „dnia akademickiego" z okazji 20-lecia nowego KPK w 2003 roku. Papież wspomniał wówczas o dwóch niebezpiecznych redukcjonizmach: lokowania Kodeksu poza tradycją prawną Kościoła oraz usiłowania interpretowania i aplikowania praw kościelnych w oddzieleniu od doktryny magisterium. Tymczasem tak dyscyplina kanoniczna, jak i magisterium sytuują się na tej samej linii: nauczania, promowania i ochrony prawdy. Poza tym autor dotyka kwestii sytuacji małżeństw nieregularnych, proponując, by żyjący w takich związkach mogli pełnić urzędy i posługi kościelne. Zauważa, że jeśli Amoris laetitia zachęca do integracji takich wiernych, gdyż nie są odłączeni od Kościoła, to należałoby badać w danej sytuacji wymogi dotyczące ich zdolności i stosowności podejmowania określonych zadań.

Giuseppe Bonfrante jest autorem przedłożenia pt. „Miłość jednoczy: nierozerwalność i sakramenty w Amoris laetitia” (s. 159-170). Omawiając tę kwestię, akcentuje potrzebę właściwego rozumienia obu aspektów wymienionego dokumentu.

„Pewność nieważności własnego małżeństwa: wpływ na porządek procesowy" (s. 171-198) to tytuł artykułu Salvatore Berlingò. Autor ukazuje kompatybilność i wzajemne przenikanie między miłosierdziem, troską duszpasterską oraz poprawnym i słusznym 
wykonywaniem funkcji sądowniczej w procesach małżeńskich. Nawiązując do waloryzacji w procesach małżeńskich brania pod uwage przekonania podmiotów o nieważności własnego małżeństwa, autor sądzi, iż być może byłoby czymś korzystnym bardziej stanowcze odwołanie do favor veritatis i do poszukiwania prawdy co do węzła małżeńskiego, które to poszukiwanie powinno kierować działaniem sędziego i całego Kościoła.

Chiara Minelli podjęła temat: „Małżeństwo cywilne i związki osób żyjących na sposób małżeński w nowej refleksji kościelnej” (s. 199-223). Nawiązując do n. 76 Amoris laetitia, autorka przywołuje liczne przemówienia papieskie kierowane do Roty Rzymskiej. Przyjmuje, iż chodzi o zaoferowanie duszpasterstwu rozwiązań bardziej skutecznych według narzędzi prawnych, którymi Kościół dysponuje; nie abstrahując od nich, przy uznaniu suwerenności zgody małżeńskiej, istnieje możliwość konwalidacji w stosunku do tych, którzy żyją w niektórych sytuacjach nieregularnych.

Wreszcie Vincenzo Varone, w artykule „Dostępność do procesu o nieważność małżeństwa” (s. 225-233), podkreśla przede wszystkim, że owa dostępność wyraża się w możliwości, danej wiernemu, zrozumienia prawdy o własnym małżeństwie. Taką możliwość mają wszyscy wierni; pomagają w tym struktury przeznaczone do konsultacji przedprocesowej.

Niewątpliwie zaprezentowana praca zbiorowa kanonistów włoskich zasługuje na uznanie i szersze zapoznanie się z poszczególnymi przedłożeniami referentów 50. Kongresu Stowarzyszenia Kanonistyki Włoskiej. 